\title{
PENGARUH HASIL BELAJAR MATA KULIAH PENDIDIKAN AGAMA ISLAM DAN PENDIDIKAN KARAKTER TERHADAP PERKEMBANGAN PERILAKU MAHASISWA DI PERGURUAN TINGGI UMUM.
}

\author{
Siti Seituni \\ STKIP PGRI Situbondo \\ siti_seituni@stkippgri-situbondo.ac.id
}

\begin{abstract}
ABSTRAK
Pembelajaran didalam dunia pendidikan adalah proses penting dalam menghasilan nilai dan tingkah laku kongkrit serta factor terciptanya sebuah pendidikan yang keduanya saling bersinergi, yang mana pendidikan merupakan sentral dalam menciptakan perubahan sikap dan prilaku yang lebih baik. Penelitian ini merupakan penelitian kuantitatif non eksperimen yang membahas bagaimana pengaruh hasil belajar mata kuliah agama islam dan pendidikan karakter terhadap tingkah laku mahasiswa. Terdapat tiga variabel yaitu hasil belajar Mata kuliah pendidikan agama islam $\left(x_{1}\right)$ dan pendidikan karakter $\left(x_{2}\right)$ Sedangkan variabel terikat adalah tingkah laku $(y)$. menganalisis data dengan menggunakan statistik deskriptif dan parametrik. Selanjutnya dilakukan uji korelasi menggunakan uji korelasi Product Moment dan dilakukan analisis regresi linier berganda. Hasil penelitian hasil menunjukkan bahwa Nilai agama dan nilai pendidikan karakter berpengaruh terhadap tingkah laku secara individu maupun serempak.
\end{abstract}

Kata kunci: regresi linier berganda, hasil belajar pendidikan agama islam, pendidikan karakter, tingkah laku mahasiswa. 


\begin{abstract}
Learning in the world of education is an important process in producing concrete values and behaviors as well as factors for the creation of education, both of which are synergistic, in which education is central in creating a change in attitudes and better behavior. This research is a quantitative non-experimental study that discusses how the influence of learning outcomes in Islamic subjects and character education on student behavior. There are three variables namely learning outcomes Islamic education and character education courses While the dependent variable is behavior. analyze data using descriptive and parametric statistics. Furthermore, the correlation test is carried out using the Product Moment correlation test and multiple linear regression analysis is performed. The results of the results show that religious values and the value of character education have an influence on individual and simultaneous behavior.
\end{abstract}

Keywords: Multiple Linear Regression, learning outcomes of Islamic religious education, character education, student behavior.

\title{
PENDAHULUAN
}

Hasil belajar merupakan nilai atas dasar proses pembelajaran yang ditungjukan oleh sikap dan prilaku yang lebih baik. Hasil belajar adalah dapat dijelaskan dengan memahami dua kata yang membuat itu, "hasil" dan "belajar". Arti dari hasil menunjukkan keuntungan karena aktivitas atau proses yang mengakibatkan perubahan masukan fungsional, sementara belajar adalah proses perubahan individu yang berinteraksi dengan lingkungan untuk mengubah perilaku. Hasil pembelajaran adalah perubahan yang mengakibatkan perubahan sikap dan perilaku manusia. (Purwanto, 2009, 38-45) Belajar bentuk hasil perubahan perilaku belajar setelah proses pembelajaran (Hamalik, 1989, halaman 122). Hasil pembelajaran termasuk kemampuan kognitif, afektif dan psikomotorik. Domain kognitif adalah pengetahuan, pemahaman, aplikasi, analisis, sintesis dan evaluasi. Afektif domain adalah menerima, menanggapi, menilai, organisasi, dan karakterisasi. Domain psikomotor termasuk ritual, pra-rutin, rountinized. Psikomotor juga termasuk keterampilan produktif, teknis, fisik, sosial, manajerial, dan intelektual. (Suprijono, 2010. 54-55). 
Sedangkan belajar dan pembelajaran adalah factor terciptanya sebuah pendidikan, yang mana pendidikan merupakan sentral dalam menciptakan perubahan sikap dan yang lebih baik. Pendidikan secara bersama-sama dalam hal pendidikan umum dan agama untuk membentuk karakter seseorang. Masuknya pendidikan agama islam didalam perguruan tinggi diharapkan dapat merubah sikap dan perilaku mahasiswa menjadi lebih baik dalam membentuk karakter pribadi dan sekitar. Didalam islam, pendidikan tidak hanya dilaksanakan dalam waktu tertentu saja, tetapi dilakukan sepanjang usia (long life education). Islam memotivasi pemeluknya untuk slalu meningkatkan kwalitas keilmuan dan pengetahuan. Bukan hanya pengetahuan yang terkait urusan ukhrowi saja yang ditekankan oleh islam, melainkan pengetahuan yang terkait dengan urusan duniawi juga (Fauzi, 2016: 23).

Dalam mewujudkan karakter-karakter baik pada seseorang tidaklah mudah, terhadap pembelajaran yang diharapkan menghasilkan nilai yang lebih sempurna, namun penentuan pembelajaran yang tercantum didalam kurikulum khususnya pendidikan agama islam dan pendidikan karakter diharapkan dapat mampu mencetak generasi muda yang religious dan berpengetahuan. Di dalam (Fitri, 2012: 22) pendidikan karakter bertujuan membentuk dan membangun pola pikir, sikap, dan prilaku peserta didik agar menjadi pribadi yang positif, berakhlak karimah, berjiwa luhur, dan bertanggung jawab. Sebagaimana disebutkan didalam Al-Qur'an surat al-Anbiya: 170: "Dan tidaklah kami mengutus kamu Muhammad SAW, melainkan untuk menjadi rahmat bagi semesta alam". Sedangkan bentuk-bentuk kerahmatan Allah pada ajaran islam sebagaimana berikut :

1. Islam menunjukkan manusia jalan hidup yang benar

2. Islam memberikan kebebasab kepada manusia untuk menggunakan potensi yang diberikan oleh Allah

3. Islam menghormati dan menghargai manusia sebagai hsmbs Allah, baik muslim atau yang beragama lain.

4. Islam mengatur pemanfaatan alam secara baik dan proporsional. (Tolchah Dkk. 2016: 66).

Mata kuliah pendidikan agama islam dan pendidikan karakter dapat saling berhubungan dalam membentuk atau membantu perkembangan karakter dan hasil belajar. Oleh karna nya riset ini bertujuan untuk mengukur efek tingkah laku dengan diukur oleh hasil belajar pendidikan agama islam dan pendidikan karakter. Seperti yang telah dibahas didalam penelitian terdahulu didalam jurnal internasional yang berjudul The Effect Of Islamic Education Learning (Pai) And Learning Results To Student's Religious Behavior Of Stisip Widyapuri Mandiri Sukabumi Student yang ditulis oleh Mu'min. U. A. dengan hasil pembahasan ada pengaruh antara pembelajaran PAI dan hasil belajar terhadap perilaku religius siswa secara positif dan signifikan. Perilaku religius seseorang bisa berubah karena adanya perubahan dalam pengertian agamanya. Secara kausal, tingkat rasa 
religius seseorang dapat dipengaruhi oleh frekuensi ilmu agama yang diakuisisi baik dari pembelajaran PAI maupun pembelajaran non formal lainnya.

\section{METODE PENELITIAN}

Penelitian dilakukan di STKIP PGRI Situbondo dengan waktu penelitian tiga bulan. Data yang digunakan dalam penelitian ini merupakan data sekunder yang bersumber dari data base akademik STKIP PGRI Situbondo. STKIP PGRI Situbondo adalah perguruan tinggi umum yang bersaing didalam dunia pendidikan dalam hal mencetak generasi bangsa yang beriman yaitu angkatan 2016 dan angkatan 2017 yang seluruhnya berjumlah 87 orang. Sampel yang diambil yaitu sebanyak 60 orang.

Penelitian ini merupakan penelitian kuantitatif non eksperimen. Terdapat tiga variabel dalam penelitian ini. dua variabel bebas antara lain hasil belajar matakuliah pendidikan agama islam $\left(x_{1}\right)$, hasil belajar matakuliah pendidikan karakter $\left(x_{2}\right)$. Sedangkan variabel terikat adalah tingkah laku (y). Data yang terkumpul dianalisis dengan menggunakan statistik parametrik, yaitu uji autokorelasi, heteroskedastisitas, multikolinieritas, normalitas, dan linieritas. Selanjutnya dilakukan uji korelasi menggunakan uji korelasi Product Moment dan dilakukan analisis regresi linier berganda.

Analisis korelasi digunakan untuk mengukur koefisien korelasi $(r)$ atau hubungan antara variabel bebas dengan variabel terikat. Analisis korelasi yang digunakan adalah korelasi Product Moment. Nilai $r$ terbesar adalah +1 menunjukkan korelasi positif sempurna dan $r$ terkecil adalah -1 menunjukkan korelasi negatif sempurna. Nilai $r$ positif menunjukkan bahwa semakin besar variabel bebas, maka semakin besar pula variabel terikat atau sebaliknya. Nilai $r$ negatif menunjukkan bahwa semakin besar variabel bebas, maka semakin kecil variabel terikat atau sebaliknya.

Rumus korelasi product moment variabel bebas $X$ dengan variabel terikat $Y$ adalah (Riduwan, 2010)

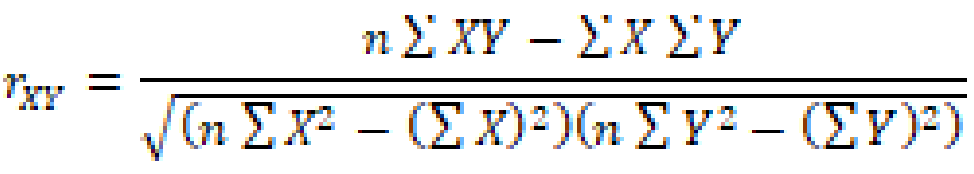

dengan

$r_{X Y} \quad=$ koefisien korelasi antara variabel $X$ dan variabel $Y$

$\sum X \quad=$ jumlah skor $X$

$\Sigma Y \quad=$ jumlah skor $Y$

$n \quad=$ banyak data 
Analisis regresi linier berganda digunakan untuk mengukur pengaruh antara lebih dari satu variabel bebas terhadap variabel terikat. Untuk mencari besarnya pengaruh tersebut digunakan rumus sebagai berikut (Sugiono, 2011)

\section{$Y=a+b_{1} X_{1}+b_{2} X_{2}+\cdots+b_{n} X_{n}$}

dengan

$Y \quad=$ variabel terikat

$X_{1}, X_{2} \quad=$ variabel bebas

a $\quad=$ koefisien regresi

$b_{1}, b_{2} \quad=$ koefisien regresi

Nilai $a, b_{1}$, dan $b_{2}$ dapat diperoleh dari

$b_{1}=\frac{\left(\sum X_{2}^{2}\right)\left(\sum X_{1} Y\right)-\left(\sum X_{1} X_{2}\right)\left(\sum X_{2} Y\right)}{\left(\sum X_{1}^{2}\right)\left(\sum X_{2}^{2}\right)-\left(\sum X_{1} X_{2}\right)^{2}}$

$b_{2}=\frac{\left(\sum X_{1}^{2}\right)\left(\sum X_{2} Y\right)-\left(\sum X_{1} X_{2}\right)\left(\sum X_{1} Y\right)}{\left(\sum X_{1}^{2}\right)\left(\sum X_{2}^{2}\right)-\left(\sum X_{1} X_{2}\right)^{2}}$

$a=\frac{\sum Y}{n}-b_{1}\left(\frac{\sum X_{1}}{n}\right)-b_{2}\left(\frac{\sum X_{2}}{n}\right)$

dengan

$\sum X \quad=$ jumlah skor $X$

$\Sigma Y \quad=$ jumlah skor $Y$

\section{HASIL DAN PEMBAHASAN:}

Analisis Statistik Deskriptif

Analisis statistik deskriptif bertujuan untuk menggambarkan perilaku tiap variabel secara umum, sehingga dapat melihat seberapa besar kaitan antara variabel bebas yaitu nilai pendidikan Agama Islam, nilai pendidikan karakter, dapat mempengaruhi tingkah laku sebagai variabel terikat. Analisis statistik deskriptif dari variabel-variabel yang digunakan dalam penelitian ini terdapat dalam Tabel 1 . 


\begin{tabular}{|c|c|c|c|}
\hline & ATTITUDE & AGAMA & KARAKTER \\
\hline Mean & 3.300000 & 3.033333 & 3.050000 \\
\hline Median & 3.000000 & 3.000000 & 3.000000 \\
\hline Maximum & 4.000000 & 4.000000 & 4.000000 \\
\hline Minimum & 2.000000 & 0.000000 & 0.000000 \\
\hline Std. Dev. & 0.743332 & 1.040969 & 1.015557 \\
\hline Skewness & -0.539330 & -1.703075 & -0.883411 \\
\hline Kurtosis & 2.002070 & 5.733028 & 3.093624 \\
\hline Jarque-Bera & 5.398424 & 47.67825 & 7.826067 \\
\hline Probability & 0.067258 & 0.000000 & 0.019980 \\
\hline Sum & 198.0000 & 182.0000 & 183.0000 \\
\hline Sum Sq. Dev. & 32.60000 & 63.93333 & 60.85000 \\
\hline Observations & 60 & 60 & 60 \\
\hline
\end{tabular}

Tabel 1. Nilai Mean, Median, Maksimum, Minimum, dan Standard Deviasi 


\section{Uji Asumsi Parametrik}

1. Uji Autokorelasi

Breusch-Godfrey Serial Correlation LM Test:

\begin{tabular}{llll} 
F-statistic & 0.040762 & Prob. F(2,55) & 0.960087 \\
Obs*R-squared & 0.088804 & Prob. Chi-Square(2) & 0.956570 \\
\hline \hline
\end{tabular}

Tabel 2. Uji Autokorelasi

Berdasarkan uji autokorelasi dengan uji Breusch Godfray (BG) menunjukkan nilai Prob.Chi-Square(2) adalah 0.956570 lebih besar dari tingkat signifikansi 5\% (0.05). Maka dapat disimpulkan bahwa tidak terjadi autokorelasi.

2. Uji Heteroskedastisitas

White Heteroskedasticity Test:

\begin{tabular}{llll}
\hline \hline & & & \\
& & & \\
F-statistic & 23.77973 & Prob. F(5,54) & 0.000000 \\
Obs*R-squared & 41.26070 & Prob. Chi-Square(5) & 0.000000 \\
\hline \hline
\end{tabular}

Tabel 3 Uji Heteroskeditas 
Berdasarkan uji heteroskedastisitas dengan uji White menunjukkan nilai Prob.ChiSquare(5) adalah 0.651734 lebih besar dari tingkat signifikansi 5\% (0.05). Maka dapat disimpulkan bahwa tidak terjadi heteroskedastisitas (homoskesdastisitas).

3. Uji Multikolinieritas

\begin{tabular}{|c|c|c|}
\hline & AGAMA & KARAKTER \\
\hline AGAMA & 1.000000 & 0.710528 \\
\hline KARAKTER & 0.710528 & 1.000000 \\
\hline
\end{tabular}

Tabel 4. Uji Multikolinieritas

Berdasarkan uji multikolinieritas menunjukkan korelasi parsial antar variabel bebas < 0,8. Maka dapat disimpulkan bahwa dalam model empiris tidak terdapat multikolinieritas.

4. Uji Normalitas

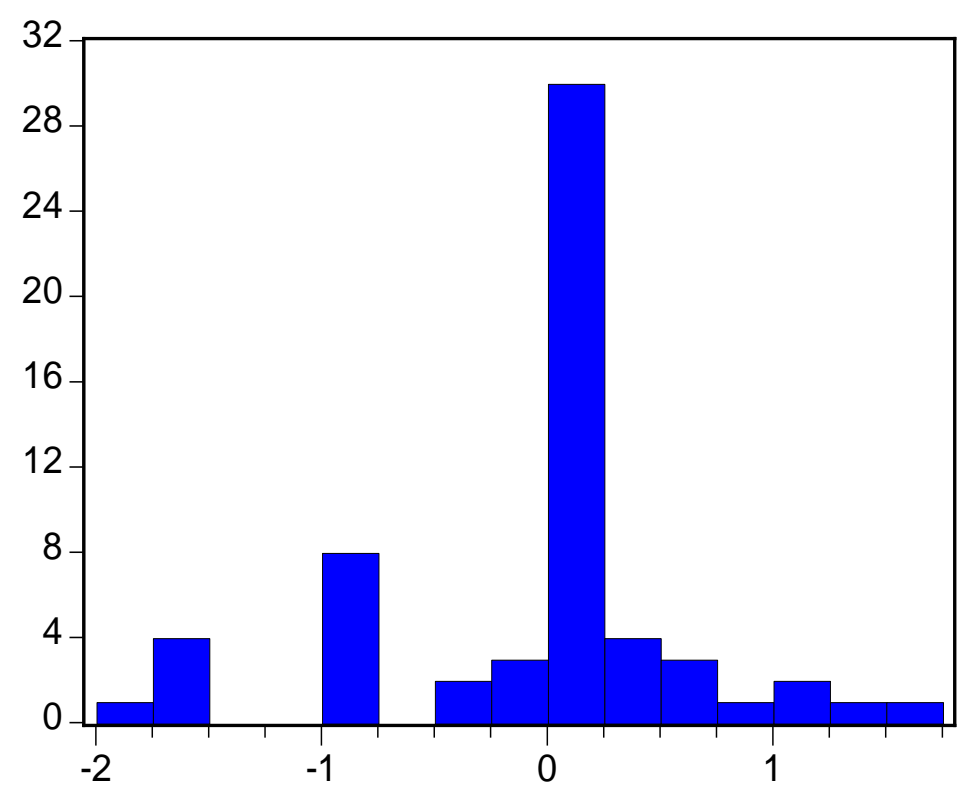

Series: Residuals

Sample 160

Observations 60

Mean

$1.43 \mathrm{e}-16$

Median

0.183419

Maximum

1.723243

Minimum

$-1.853686$

Std. Dev.

0.713016

Skewness

$-0.601660$

Kurtosis

3.741361

Jarque-Bera 4.993992

Probability $\quad 0.082332$

Gambar 5. Uji Normalitas 
Berdasarkan hasil uji normalitas menunjukkan nilai probabilitas 0.082332 lebih kecil dari tingkat signifikansi 5\% (0.05). Maka dapat disimpulkan bahwa eror tidak berdistribusi normal.

5. Uji Linieritas

Ramsey RESET Test:

\begin{tabular}{llll}
\hline \hline & & & \\
F-statistic & 1.023199 & Prob. F(1,56) & 0.316112 \\
Log likelihood ratio & 1.086389 & Prob. Chi-Square (1) & 0.297273 \\
\hline \hline
\end{tabular}

Tabel 6. Uji Linieritas

Berdasarkan hasil uji linieritas dengan uji Ramsey Test menunjukkan nilai Prob.ChiSquare(1) adalah 0.297273 lebih besar dari tingkat signifikansi 5\% (0.05). Maka dapat disimpulkan bahwa model linier.

\section{Analisis Korelasi}

Setelah diketahui bahwa data yang diperoleh memenuhi uji asumsi klasik, maka dilakukan analisis korelasi. Pengujian hipotesis menggunakan Korelasi Product Moment yang hasilnya dijabarkan dalam Tabel 7.

\section{ATTITUDE AGAMA KARAKTER}

$\begin{array}{cccc}\text { ATTITUDE } & 1.000000 & 0.709696 & 0.810528 \\ \text { AGAMA } & 0.709696 & 1.000000 & 0.671769 \\ \text { KARAKTER } & 0.810528 & 0.671769 & 1.000000\end{array}$

Tabel 7. Koefisien Korelasi Antar Variabel 
Koefisien korelasi antara pendidikan agama dan tingkah laku sebesar 0.709696, artinya berkorelasi positif tinggi. Koefisien korelasi pendidikan karakter dan tingkah laku sebesar 0.819528 , artinya berkorelasi positif sangat tinggi.

\section{Analisis Regresi Linier Berganda}

Dependent Variable: ATTITUDE

Method: Least Squares

Date: 01/16/18 Time: 17:43

Sample: 160

Tabel 8.

Regresi

\begin{tabular}{ccccc}
\hline \hline & & & & \\
Variable & Coefficient & Std. Error & t-Statistic & Prob. \\
\hline \hline AGAMA & 0.214992 & 0.069149 & 3.109089 & 0.0029 \\
KARAKTER & 0.445223 & 0.070880 & 6.281394 & 0.0000 \\
C & 1.289927 & 0.180567 & 7.143751 & 0.0000 \\
\hline \hline & & & & \\
R-squared & 0.706696 & Mean dependent var & 3.300000 \\
Adjusted R-squared & 0.696405 & S.D. dependent var & 0.743332 \\
S.E. of regression & 0.409572 & Akaike info criterion & 1.101298 \\
Sum squared resid & 9.561702 & Schwarz criterion & 1.206015 \\
Log likelihood & -30.03895 & F-statistic & 68.66890 \\
Durbin-Watson stat & 1.626889 & Prob(F-statistic) & 0.000000 \\
\hline \hline
\end{tabular}

\section{Berganda}


Berdasarkan Tabel 8 di atas, persamaan regresi linier berganda yang terbentuk adalah $y=1.289927+0.214992 \mathrm{x}_{1}+0.445223 \mathrm{x}_{2}$ dapat dijelaskan bahwa

a. Nilai konstanta 1.289927 berarti apabila variabel nilai Agama $\left(x_{1}\right)$ dan nilai pendidikan karakter $\left(x_{2}\right)$ konstan, maka persentase tingkah laku $(y)$ akan mengalami peningkatan sebesar $1.289927 \%$.

b. Koefisien regresi dari variabel bebas nilai agama $\left(x_{1}\right)$ sebesar 0.214992 berarti bahwa apabila nilai agama $\left(x_{1}\right)$ mengalami kenaikan sebesar $1 \%$ dengan asumsi nilai pendidikan karakter $\left(x_{2}\right)$ konstan, maka menyebabkan persentase tingkah laku $(y)$ mengalami peningkatan sebesar $0.214992 \%$.

c. Koefisien regresi dari variabel bebas nilai pendidikan karakter $\left(x_{2}\right)$ sebesar 0.445223 berarti bahwa apabila nilai pendidikan karakter $\left(x_{2}\right)$ mengalami kenaikan sebesar $1 \%$ dengan asumsi nilai agama $\left(x_{1}\right)$ konstan, maka menyebabkan persentase tingkah laku (y) mengalami peningkatan sebesar $0.445223 \%$.

\section{Uji Hipotesis}

Pengujian hipotesis berdasarkan pada uji statistik, yaitu pengujian simultan (serempak) dengan uji-F, pengujian parsial (individu) dengan uji-t, dan pengujian koefisien determinasi $\left(R^{2}\right)$.

\section{a. Pengujian simultan (serempak) dengan uji-F}

Berdasarkan hasil analisis regresi linier berganda pada Tabel 4.8 diperoleh nilai probabilitas $F_{\text {hitung }}$ sebesar 0.000000 yang lebih kecil dari tingkat signifikansi $\alpha=0,05$ (5\%) yang menyebabkan hipotesis nol $\left(\mathrm{H}_{0}\right)$ ditolak. Sehingga dapat disimpulkan bahwa variabel nilai agama $\left(x_{1}\right)$ dan nilai pendidikan karakter $\left(x_{2}\right)$ secara serempak mempunyai pengaruh terhadap tingkah laku $(y)$.

\section{b. Pengujian parsial (individu) dengan uji-t}

Berdasarkan hasil analisis regresi linier berganda pada Tabel 4.8 diperoleh nilai $t_{\text {hitung }}$ variabel nilai agama $\left(x_{1}\right)$ sebesar 3.109089 dengan nilai probabilitas sebesar 0.0029 yang lebih kecil dari tingkat signifikansi $\alpha=0,05$ (5\%). Sehingga dapat disimpulkan bahwa variabel nilai agama $\left(x_{1}\right)$ secara individu mempunyai pengaruh tingkah laku $(y)$.

Nilai $t_{\text {hitung }}$ variabel nilai pendidikan karakter $\left(x_{2}\right)$ sebesar 6.281394 dengan nilai probabilitas sebesar 0.000 yang lebih kecil dari tingkat signifikansi $\alpha=0,05$ (5\%). 
Sehingga dapat disimpulkan bahwa variabel nilai pendidikan karakter $\left(x_{2}\right)$ secara individu mempunyai pengaruh terhadap tingkah laku $(y)$.

\section{c. Pengujian koefisien determinasi $\left(R^{2}\right)$}

Berdasarkan hasil analisis regresi linier berganda pada Tabel 4.8 diperoleh nilai koefisien determinasi $\left(R^{2}\right)$ sebesar 0.706696 yang berarti bahwa $70.6696 \%$ tingkah laku $(y)$ dipengaruhi oleh variabel nilai agama $\left(x_{1}\right)$ dan nilai pendidikan $\left(x_{2}\right)$. Sedangkan sisanya sebesar 29,3304\% tingkah laku (y) dipengaruhi oleh variabel-variabel lain di luar model.

\section{KESIMPULAN}

1. Nilai agama dan nilai pendidikan karakter secara serempak mempunyai pengaruh terhadap tingkah laku.

2. Nilai agama secara individu mempunyai pengaruh terhadap tingkah laku.

3. Nilai pendidikan karakter secara individu mempunyai pengaruh terhadap tingkah laku.

\section{SARAN}

Dari hasil penelitian menunjukkan bahwa Nilai agama dan nilai pendidikan karakter berpengaruh terhadap tingkah laku secara individu maupun serempak. Oleh karena itu, dalam membentuk karakter mahasiswa dibutuhkan pembelajaran agama dan pendidikan karakter.

\section{DAFTAR PUSTAKA}

Fitri, A. Z. 2012. Pendidikan Karakter Berbasis Nilai Dan Etika Di Sekolah. Ar-Ruz Media:

Djogjakarta.

Hamalik, 2011, Kurikulum dan Pembelajaran, Jakarta: Bumi Aksara.

Mu'min, U. A. 2017. The effect of Islamic Education Learning (PAI) and Learning Results to

Student's Religious Behavior of Stisip Widyapuri Mandiri Sukabumi Student. Purwanto, 2009, Evaluasi Hasil Belajar, Yogyakarta: Pustaka belajar.

Riduwan. 2010. Skala Pengukuran Variabel-variabel Penelitian. Bandung: Alfabeta.

Sugiono. 2011. Metode Penelitian Pendidikan, Pendekatan Kuantitatif, Kualitatif, dan $R \& D$

Bandung: Afabeta.

Suprijono, 2010, Cooperative Learning, Yogyakarta. Pustaka Belajar.

Tolchah Dkk. 2016. Pendidikan Agama Islam. Madani: Malang. 